\title{
The Perevodchik-Terjiman Newspaper: A Bilingual Phenomenon of the Muslim Press in Late Imperial Russia
}

This case study examines the bilingualism of the prominent Russian Muslim newspaper of the late nineteenth to early twentieth centuries, known as the Perevodchik-Terjiman (literally "Translator" or "Interpreter") by means of discourse analysis. This newspaper was published from 1883 to 1918 in Crimea, until 1914 by Ismail Gasprinskii (1851-1914), a prominent enlightener of Russian Muslims. Until December 1905, the newspaper was issued in two languages-Russian and so-called common-Turkic. The latter language was unsuccessfully intended to become a common literary language for Russian Muslims. Despite the declarations, the parallel articles in Russian and Turkic barely presented direct translations from one language to another. On the contrary, there were significant differences. The differences in Russian and Turkic narratives were not markers of opposing intentions or obscure meanings. It is argued here that this feature can be qualified as an instance of cultural bilingualism, which reflected the multiculturalism of the newspaper's heterogeneous audience. 


\section{Introduction}

At the turn of the twentieth century, there were just a few Muslim newspapers in Turkic languages in the late Russian Empire. The most influential among them was the Perevodchik-Terjiman newspaper (hereinafter, the Terjiman ${ }^{1}$ ), published for over thirty years in Crimea by Ismail Gasprinskii (1851-1914), a prominent enlightener of Russian Muslims. Until December 1905, the newspaper was issued as bilingual, parallel texts published in two languages-Russian and so-called common-Turkic. This fact was captured in its name, which literally means "Translator" or "Interpreter."

The Terjiman assumed that along with educational reform, national press, and "new literature," the common-Turkic language would become a common literary language for Russian Muslims, or at least for Russian Muslim Turks, imaged as a common "nation" within the Russian empire. At the same time, the Terjiman advocated for Muslims' duty to learn the Russian language. In doing so, it promoted further integration of Muslims into imperial society with the preservation of their cultural particularism. Hence, as Peter M. Judson exemplified in the case of the Austro-Hungarian empire, the concepts of nationhood and ideas of empire "developed in dialogue with each other, rather than as binary opposites" $(2016,9)$. In this sense, the Terjiman's bilingualism could be qualified as a reflection of imperial multiculturalism.

At the same time, the Terjiman, which until 1905 was in some way the monopolist in the Muslim media sphere in the Russian Empire, could be considered in terms of Pierre Bourdieu's concept of symbolic power. It is particularly notable in cases in which the Terjiman's editorial staff retranslated its progressist position as common for all Russian Muslims or presented its own vision of socio-political developments on behalf of the Muslim population as a whole. In addition, according to Bourdieu, "In the case of symbolic production, the constraint exercised by the market via the anticipation of possible profit naturally takes the form of an anticipated censorship, of a self-censorship which determines not only the manner of saying, that is, the choice of language-'code-switching' in situations of bilingualism-or the 'level' of language, but also what it will be possible or not possible to say" $(1991,77)$. Particularly, self-censorship in this sense can be

1 I have chosen the Latin spelling "Terjiman" due to its official denomination by Ismail Gasprinskii according to Crimean Tatar phonetical rules. As far as newspapers that were published in Arabic script, there are some other possible spellings, such as "Tarjuman" and "Terjuman." 
defined within the differences between Russian and Turkic narratives in the Terjiman.

Moreover, the newspaper's bilingualism gives rise to numerous speculations about its content or even ideological bent (which, incidentally, was loyal and statist) even after 1905 in the circumstances of the increasing socio-political demands of Muslims. As many of the articles of the Terjiman consisted of at least two discourses of a different nature (such as nationalistic but loyal or European-style progressive but religious), they can be read variously depending on the recipient and his anticipations. For instance, according to Yusuf Akçura, the Terjiman should be "read between lines" due to the censorship in the Russian Empire, while Gasprinskii himself should be acknowledged as an all-Turkic nationalist-in other words, "pan-Turkist" (Akçura 1978, 91-102). Still, the comparison between parallel Russian and Turkic articles in the Terjiman shows none of the opposing intentions or obscure meanings but largely the shift of the emphasis.

Thus, the case of the Terjiman's bilingualism, exemplifying no literal translation from Russian into Turkic or vice-versa, might provide new insights into nationalism studies in the imperial context, as well as enrich media studies in terms of the symbolic power it presents.

Despite the wide scientific coverage of the language issue in the Terjiman, there is no consensus regarding the definition of the Turkic language used in this newspaper. Many researchers agree that the newspaper used a simplified version of the Ottoman-Turkish language with local Tatar elements (Kırımlı 2001; Gubaydullin 1997). However, some consider the language to be Old Crimean Tatar (Kurkchi 1986) or common-Turkic (Yaman 2002), without providing an exhaustive definition of the latter. Moreover, most of the studies on this newspaper's language focus either on the linguistic features of its Turkic section (Kurkchi 1986) or on the role of the common literary language for Russian Muslim Turks in the ideological aspect (Akçura 1978; Gubaydullin 1997).

At the same time, there are also scholars who deal with the bilingualism of the Terjiman in a broader context, such as the emergence of the Muslim intelligentsia or the newspaper's history (Tuna 2017; Lazzerini 1992).

In my turn, I address the phenomenon of the Terjiman's bilingualism itself as a particular feature of this newspaper. Addressing the bilingualism of the Terjiman by means of discourse analysis, I imply the structuralist approach, initially based on the linguistic theory of Ferdinand de Saussure. At the same time, in accordance with Bourdieu's methodology,

As many of the articles of the Terjiman consisted of at least two discourses of a different nature (such as nationalistic but loyal or European-style progressive but religious), they can be read variously depending on the recipient and his anticipations. 
I examine the Terjiman's discourse in terms of language as symbolic capital. In this sense, the Terjiman's intentions to create a common literary language for Russian Muslims should be qualified as an attempt to define their linguistic habitus, as well as its monopolistic role in the field of Muslim press until 1905, to establish a dominant discourse among Russian Muslims. Furthermore, I define the newspaper's inequal bilingual appeals to a multicultural audience (Muslim and non-Muslim) as cultural bilingualism, therefore, redefining the term suggested by Yuriy Lotman, who speaks about cultural bilingualism as a frontier zone, "providing the semiotic contacts between two worlds" (1992, 15).

The first stage of this research was the selection process. The statement quotes were selected due to their relevance to revolutionary events in the Russian Empire in 1905. Subsequently, all 110 issues of this newspaper in 1905 were consulted. At the same time, the terminology samples exemplify the features of the Terjiman's socio-political and religious discourse from the whole "bilingual" period between 1883 and 1905.

In the second stage, I implemented structural discourse analysis on the selected items, focusing on newspaper's terminology features as well as on differences between Turkic and Russian texts.

The items exemplified in this research are open-access, digitalized copies of the Terjiman from 1883 to 1905 , published on the official website of the Russian National Library in Saint Petersburg. ${ }^{2}$

\section{Ismail Gasprinskii and the Terjiman Newspaper in the Russian Imperial Context}

First, I suggest that a brief review of the biography of Gasprinskii, whose life story can be explained as a model biography of an imperial national activist in the period under consideration, as well of the Terjiman's pre-history, could help to better contextualize the newspaper's discourse.

Ismail Gasprinskii was born in Crimea in 1851. His father, Mustafa Gasprinskii, was a military translator who, by his service, obtained nobility status for his heirs. Gasprinskii received his primary education at a mekteb (elementary Muslim school) in Bakhchisarai, then attended secondary school in Simferopol. He continued his studies at the military schools in Voronezh and Moscow but did not complete the full course (Gankevich 2001, 138-40). From 1871 to 1874 he lived in

2 See http://nlr.ru/res/inv/ukazat55/record_full.php?record_ID=193088. Accessed April, 16, 2021. 
Paris and then spent a year in Istanbul, where he tried to enroll in a military school. Upon being refused, he returned to Crimea. Between 1878 and 1884, Gasprinskii was engaged in political activity, being first a member of the city council and then the deputy mayor and mayor of Bakhchisarai, respectively. After several years of attempts to establish his own newspaper, he finally succeeded in getting a license for the Terjiman in 1883 (Lazzerini 1992, 144-6). Henceforth, publishing activities became his life-long project. Consequently, Gasprinskii's strong attempt to establish own media outlet reflects his understanding of the consolidation potential of newspapers, which he systematically referred to as "a language of people."

Ismail Gasprinskii was one of the key figures in the educational movement among Russian Muslims, known as Jadidism. Jadidism took its name from the renewed educational method usul-i jadid (literally "new method"), which Gasprinskii actively popularized in the Terjiman. However, contrary to common belief, Gasprinskii was not the only pioneer in the implementation of the usul-i jadid in the Russian Empire, as he testified to himself in the Terjiman (Terjiman 1883).

There are several opinions about the emergence of usul-i jadid and its correlation with Gasprinskii's activities (Landa 2011, 144-5). According to the Cambridge History of Turkey, usul-i jadid emerged in the Ottoman Empire as early as the Tanzimat period (1839-1876), eventually spreading into Central Asia, where its adherers became known as Jadids (Findley 2008, 22-23). However, according to Adeeb Khalid, it was Gasprinskii who inspired the emergence of Jadidism in Russia, including its Central Asian realms and protectorates (Khalid 2010, 81-2, 93). These controversies notwithstanding, the so-called new method schools gradually spread among Muslims in Russia and beyond. The all-Russian Jadidism as an educational movement was clearly inspired by Gasprinskii's activities including those in the Terjiman. Additionally, Gasprinskii's aspiration for educational reform could be better illustrated in the following statement: "education is the soul and strength of every nation" (Terjiman 1890).

It is also common to find Ismail Gasprinskii's name among the ideologists of Pan-Turkism (Akçura 2015, 104-6; Gökalp 2017, 12-3). In particular, the slogan Dilde, fikirde, işte birlik (Unity in language, thoughts, and business), which emerged in the Terjiman in October 1912 , is sometimes interpreted as an appeal to a worldwide political union of the Turks under the auspices of the Ottoman Empire. In this case, the ideas of Gasprinskii are wrongly presented as anti-Russian or even separative. What he actually advocated for was the consolidation 
of Russian Muslims on the basis of a common religion (Islam) and language (so-called common-Turkic) but in order to secure national-cultural (non-territorial) autonomy for Muslims within the Russian Empire (Tsibenko and Tikhonova 2019).

The Terjiman was published in Bakhchysarai (the former capital of the Crimean Khanate) from 1883 to 1918 and served as a significant informational platform for Russian Muslims. According to Edward Lazzerini, the Terjiman's "very existence, was constant testimony to veritable revolution in communication", which changed "not only a nature of public discourse, but its level and impact as well” (Lazzerini 1992, 154). However, being a media outlet, the Terjiman presented the opinion of a certain social group-in this case, Russian Muslim progressives.

In the light of the liberalization of the Russian press in 1905, between 1906 and 1908 the Terjiman was almost entirely published in Turkic, except for official documents, announcements, advertisements, and some articles in Russian. In 1908, the newspaper's Russian section was restored as an independent part, which henceforth did not necessarily have a parallel text in Turkic and was significantly inferior in its volume. Since then, the Russian section became a platform for polemics with other Russian newspapers or public figures on issues related to the internal life of Russian Muslims, as there was a significantly increased interest in this topic after the First Russian Revolution of 1905-1907.

From 1891 to 1903 the Terjiman was the only private Muslim newspaper in the Russian Empire. While other Russian Muslim newspapers in Turki, such as Ekinci or Keshkul, were closed after their short existence, the longevity of the Terjiman can be explained by, among other reasons, its bilingualism. Russian section though contributed more to a credit of the authorities in terms of censorship, rather than directly whipped up the popularity of the newspaper, whose subscribers were mainly Turkic-speaking readers. The restoration of the Russian section after its almost two-year absence indicates that it was a necessity, apparently due to the strengthening of state control over Muslims, which was inspired, among other things, by the revolutions in Iran (1905-1911) and Turkey (1908-1909) (Arapov 2012, 121-6).

\section{The Terjiman's Turkic Language and its Significance}

Unless we address the Terjiman's bilingualism per se, it is important to mention some features of the so-called common-Turkic language used in the newspaper, because of this language's artificial nature and signi- 
ficance in terms of Gasprinskii's intentions to consolidate the Muslim community.

Noteworthily, Gasprinskii emphasized that this language was not his individual invention but, rather, a "fruit of writings" of a set of contemporary authors such as Shihabeddin Marjani, Kayum Nasyri, Husain Faizkhanov, etc. (Terjiman 1905j).

However, the Terjiman's editorial staff did not have a systematic approach to the definition of the Turkic language used in the newspaper. It was called Tatar, Turkic-Tatar, Turkic, common-Turkic, the language of Muslims, etc. This non-systematic approach seems to be a result of the artificial nature of this language, as well as an attempt to meet the expectations of different audiences; some could prefer the term Tatar, while others Turkic or any other. Moreover, where applicable, different languages of Russian Muslim Turks were referred to as lehçe or dialekt (dialect) but Ottoman Turkish was always qualified as a dil or yazyk (language). In addition, Gasprinskii himself denied the similarity of the newspaper's language to Ottoman Turkish (Terjiman 1905g), which did not correspond to the linguistic facts.

According to a brief linguistic analysis of the Terjiman's language, it was simplified Ottoman Turkish with a significant local Tatar element. Eclecticism was a common feature of this language due to its developing literary norm. Despite the trend towards simplification, the language was complex in terms of vocabulary and some grammar. In particular, there was the Persian ezafe-for example, kemal-i hürmet (full respect) - and an abundance of Arabic and Persian loanwords, such as rafik (friend), sene (year), rüzgar (wind), etc., some of which were used simultaneously with their Turkic counterparts.

This common-Turkic was rather difficult to understand for those who did not study it on purpose (Samoylovich 1916, 7). Still, Gasprinskii and his supporters intended to develop common-Turkic to the status of a common literary language for Russian Muslim Turks, appealing to the necessity of its widespread dissemination and adaption by means of a unified educational system (namely, new method schools), national mass media, and new literature. In this regard, Gasprinskii, through the Terjiman, actively promoted the new literature in common-Turkic, personally being an author of some novels, as well as the idea of teaching this language in new method schools.

Additionally, Gasprinskii advocated for the preservation of the traditional Arabic script for Turkic writing with its subsequent modification. Particularly, yeni imla (new spelling) was adapted in the Terjiman in 1913. The need for Arabic script was portrayed in Terjiman as an assu- 
rance of the unification of so-called common-Turkic, as the use of this graphics largely erased the phonetical differences between various Turkic languages (Tatar, Azerbaijani, etc.) but even the Arabic script could not level out existing morphological or lexical differences between them. Moreover, according to Mustafa Tuna, Gasprinskii's attitude towards the Arabic script reflected his project, aimed at the national consolidation of Russian Muslims (Tuna 2002, 270).

However, the process of forming a common literary language for Russian Muslims was not completed. It failed after the First Russian Revolution of 1905-1907, when the tendencies to develop a literary norm based on regional Turkic languages-such as Tatar, Azerbaijani, etc.-prevailed.

Despite the newspaper's official program, ensuring

that the parallel texts were "direct translations from Russian into Tatar", it could be stated that

Russian and Turkic versions corresponded

to each other with respect to the general meaning but were not literal translations from one language to another.

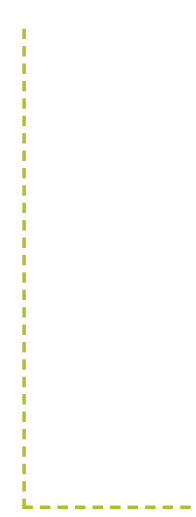

\section{The Terjiman's Bilingual Discourse}

First, while the Terjiman was published as two parallel texts in Russian and Turkic between 1883 and 1905, there were many remarkable differences in its Russian and Turkic narratives. In some cases, parallel articles had different headings; in others, there was a lack of passages in one of the versions, either Russian or Turkic. For instance, an article about Crimean Tatar emigration was titled in Russian as Vozvrachsheniye iz Turtsii (Return from Turkey), while its Turkic counterpart was termed Kidenlerin kaytuşi (Return of leavers) (Terjiman 1903).

Despite the newspaper's official program, ensuring that the parallel texts were "direct translations from Russian into Tatar", it could be stated that Russian and Turkic versions corresponded to each other with respect to the general meaning but were not literal translations from one language to another. (CGAK, f. 26, op. 2, d. 1595, 1l. 17-18, 21: quoted after Kerimov 1999, 298). It should be mentioned, though, that Edward Lazzerini, with reference to Gasprinskii's statement in the Terjiman (Terjiman 1905i), questioned his proficiency in writing in Turkic and translating into this language himself (Lazzerini 1992, 153). Still, what Gasprinskii actually stated, was: "Until nowadays due to special conditions a significant part of the Terjiman was filled with useless Russian text of all that we translated for the Tatars" (Terjiman 1905i).

The second feature of the newspaper's discourse could be qualified as cultural bilingualism (a term of Y. Lotman), common to the written legacy of Russian Muslim progressives, whose monolingual texts consisted of at least two discourses of different natures. For instance, their European-style discourse of progress was supplemented with quotations 
from the Quran or Sunnah (Bessmertnaya 2019). The Terjiman's bilingual case in this sense is far more complicated but representative. Thus, speaking about the secularly defined progress, the Terjiman quoted the Quran or Sunnah in both Russian and Turkic versions. Still, many religious terms were secularized while being translated into Russian. For instance, such Islamic terms as mumin (believer, faithful Muslim) and fard (religious duty commanded by God) were translated into Russian simply as Muslim and something obligatory, respectively.

Additionally, parallel texts of the newspaper were written primarily according to recepients' expectations and cultural background, therefore further exemplifying cultural bilingualism. For instance, once addressing the Russian Muslims' emigration to the Ottoman Empire, the Russian version simply criticized the very fact of emigration, while its Turkic counterpart, beyond the critique of emigration itself, discussed whether this emigration was religiously motivated and concluded that it was not (Terjiman 1903).

Furthermore, Gasprinskii, along with other authors who wrote in common-Turkic, was, in this respect, a "legislator." He was able to determine the appearance of this language in terms of its vocabulary and grammar, hence affecting the linguistic habitus of the readers. Of particular interest in this sense is Gasprinskii's experiments with the Russian term intelligentsia (loosely, "intellectual class"), which did not have a direct equivalent in Turkic. As Mustafa Tuna exemplified, Gasprinskii initially translated Muslim intelligentsia into Turkic as erkan-i cemiyet (pillars of society), erkan-i milliye (pillars of nation), and tabaka-yz aliye (upper strata), though finally deciding on ziyalilar (enlightened). The variations in Turkic translations-all being magnific-present the value that Gasprinskii attached to Muslim intelligentsia, appointed to become a societal vanguard of the Russian Muslim community (Tuna 2017, 264-77).

However, many Russian terms were provided in a Turkic version without translation, by simple transliteration into Arabic script-for instance, gosudar' (sovereign), knyaz' (prince), zemstvo (municipality), uyezd (district), gubernator (governor), gradonachal'nik (mayor), etc. Possibly, this set of terms was intended to be fixed in common-Turkic in a transliterated form to emphasize their direct correspondence to the socio-political realities of the Russian Empire.

There was also modern phenomenon such as proletariat (proletariat), industriya (industry), and zavod (factory), which also had simply been transliterated due to the absence of translated equivalents in Turkic. At the same time, such terms as emperor (imperatorl padişah), ruler (tsarl 
malik), civil servant (chinovnik/ memur), and manifesto (manifest/ferman) were used in Turkic both as simple transliterations of Russian terms (imperator, tsar, chinovnik, manifest) or as direct translations (padişah, malik, memur, ferman). The latter set shows the eclecticism of common-Turkic in light of its developing literary norm.

Additionally, the Russian section of the Terjiman regularly used the term tuzemtsy (natives) or the single-rooted adjective tuzemny (native). This term, having a direct equivalent in Turkic (yerli), was almost entirely replaced by the terms islam or müslüman (Muslim) in the Turkic version. Only on rare cases were such collocations as yerli dil (native's language) used as an equivalent for Russian tuzemny yazyk (native's language), which, incidentally, was more frequently translated as islam dili (Muslim's language). Obviously, such terms as tuzemtsy (natives) along with inorodtsy (non-Russians) were accepted in the newspaper from the official imperial discourse but the sphere of their usage shows an absence of negative or derogative meanings. It seems that the editorial staff redefined the term tuzemtsy to emphasize the indigenousness of Muslims in Russia. In this sense, the substitution of this term in the Turkic version can be explained due to its semantic redundancy for Muslim readers, as well as an instance of self-censorship.

It is also worth distinguishing synonyms given from secular and religious contexts. For example, such terms as sharia (law) and muallim (teacher) were limited by religious sphere of usage in both Russian and Turkic, while in a secular context they were replaced by their synonyms, zakon (law) and uchitel (teacher).

Concerning the Terjiman's reflection of the socio-political status of Muslims in Russia, one should mention terminological coincidence in both Russian and Turkic versions-namely, vernopoddannye or sadakatl tebaalar (loyal subjects), patriotism or vatanperverlik (patriotism), rodina or vatan (Motherland), veroterpimost' or dine kemal-i hürmet (religious tolerance), ravnopraviye or bir derecede / adil haklar (equal / fair rights), etc. The usage of these terms indicates a positive image of the Russian Empire as their resident country and the idea of their loyalty to the authorities.

At the same time, in both the Russian and Turkic sections, one can note the terms which reflect the nationalistic orientation of the newspaper and distinguish Muslims as a particular group of Russian subjects who were nationalized by the imperial state-for instance, natsionalizm or milletperverlik (nationalism), podchinyonnye / pokoryonnye narody or zapt edilmiş / tabi edilmiş halklar (nationalized / refrained peoples), russifikatsia or ruslaşdırma (Russification), inorodtsy or gayri Ruslar (literally, "non-Russians"), etc. 


\section{The Terjiman's Bilingualism in the Context of the First Russian Revolution of 1905-1907}

In this part, I address the Terjiman's reflection of revolutionary events in Russia until December 1905, when the newspaper ceased being bilingual, namely, both within the period of existing censorship and a short while after its elimination in October 1905. I argue that even in the circumstances of a sufficiently altered political atmosphere in the Russian Empire in 1905, the Terjiman's bilingual content presented a shift in emphasis rather than obscure meanings. This shift, though, reflected the newspaper's cultural bilingualism, appointed to address different audiences-Russian and Muslim ones.

The Terjiman, being located far from the cultural-political centers of the Russian Empire, issued all-Russian political news with some delay, and based it on information from official sources and metropolitan newspapers (Novoye Vremya, Russkaya pravda, etc.). At the same time, news concerning Russian Muslims in a revolutionary context was produced by the Terjiman itself, or as referred to in Russian newspapers from different regions with a large Muslim population (Volzhskiy listok from Kazan, Kaspiy from Baku, etc.). In this regard, of particular interest is how the Terjiman bilingually represented the revolutionary events of 1905 in Russia from the perspective of both the imperial periphery and the Muslim community.

First, this newspaper, as a representative of the legal press, does not use the term Revolution in describing the events of 1905. Instead, the mass strikes, riots, and demonstrations were qualified as violent civil unrest. Moreover, the editorial staff emphasized that during the political unrest in Russia, Muslims remained loyal to official authorities, stayed away from both social-democrats and the Black Hundred, and did not participate in antisemitic acts, even being defenders of Jews. In this tone, they promised their loyalty and declared gratitude after the October Manifesto:

The Manifesto of Freedom was greeted by Muslims with great joy, full dignity, and restraint. In Crimea, in the Caucasus, in Kazan Muslims stood under the state flag, avoiding both the red flag and the Black Hundred outrages. Thank God, nowhere in the days of joy and freedom, our Turkic hand did not touch blood or other people's goods. Muslims from Kazan, Bakhchisaray and Yalta were ready to defend students and Jews from terror violence and robbery (Terjiman 1905h). 
At the same time, the Turkic version of the abovementioned passage distinctly shifted the emphasis of the information given. In contrast to its Russian version, the passage in Turkic emphasized twice the nonparticipation of Muslims in the outrages of the Black Hundred, especially in their antisemitic acts. Additionally, the Turkic version strictly criticized the far-right, monarchist movement of the Black Hundred, which emphasized the liberal position of the Terjiman:

In the demonstrations that followed the proclamation of the Manifesto of Freedom, Muslims (for example, in Baku, in Kazan, in Crimea) did not join the representatives of the red flag (that is, the members of the Social Democratic Party), but friendly greeted those who carried the Russian flag. However, in addition to these national parties, there was the "black party" [namely, Black Hundred] that blackened these glorious days with murders and outrages, so not a single Muslim joined them. There have been no reports of Muslims committing dishonor and injustice by unlawfully taking away the parts of the property of Jews or others. Muslims from Kazan, Bakhchisaray and Yalta were ready to defend students and Jews from the "black party" (Terjiman 1905h).

Apart from such statements, imaging Muslims as those who did not take part in any outrages, the Terjiman actively offered insight into the bloody events in Baku, referred to as armyano-tatarskaya reznya (Armenian-Tatar killings) in Russian or ermeni ve müsülman vurusmalar (Armenian-Muslim combat) in Turkic. The series of related articles (Terjiman 1905c; 1905e, etc.) were focused on the unacceptability of any inter-ethnic conflict and its harm for the Russian Empire, as well as on conciliatory cooperative measures by Armenian Catholicos and Muslim Shaykh al-Islam. One such event was qualified in the Terjiman as a result of anti-governmental provocations, inspired by Armenian and Russian revolutionary social democrats (Terjiman 1905c). In this context, the Tatars/ Muslims (i.e., Azeris) were presented as "the most peaceful element", enforced to "defend themselves" (Terjiman 1905c). Moreover, describing the conflict, the Terjiman made references to an 'unprejudiced actor', namely, to famous millionaire and manufacturer Nobel from Baku, whose business was harmed by the bloody events.

In addition, within the revolutionary events of 1905, the Terjiman systematically published official documents that declared the political reforms and proclaimed civil rights in Russia. Noteworthily, the Terjiman presented these changes as consequences of successive reformist activities initiated by the sovereign already in the pre-revolutionary period, rather than as political developments inspired by general socio-political unrest 
in the country. For instance, in one of the Terjiman's articles, the official decrees of 1903 and 1904, giving Russian subjects some civil rights, including religious equality, were mentioned as pathbreaking changes. The Russian version of the article stated:

Our time seems to be the most significant time in the modern history of Russia and its peoples. This time is important due to the great war that Russia is waging in the Far East, but it is even more important due to the renewal work that our Government began at the direction of the Emperor. Our readers know that in 1903 there was the Imperial Manifesto, which firmly adapted the idea of religious tolerance. The Decree of December 12, 1904, developed this great idea and graciously outlined many other reforms inspired by the life conditions (Terjiman 1905f).

The same passage in Turkic differs in emphasis. As distinct from the Russian version, it did not stress the role of the emperor and government in current political developments, which, however, were still presented as reforms from above instead of revolution from below. Moreover, the Turkic version supplies readers with information about the "privileges for all nations" (Terjiman 1905f).

Furthermore, the Terjiman published the text of the October Manifesto of October 17, 1905 (officially, The Manifesto on the Improvement of the State Order), supplying it in Russian with comments focused on civil liberties, provided by the government:

Great, great is this day, which has become a day of all-Russian veneration, omen, and unity. The cherished dreams of people who truly love Russia and its peoples seem to have come true... The published Imperial Manifesto entails the responsibility of the United Government to implement in Russia the unshakable foundations of civil liberties on the basis of the true personal integrity, freedom of conscience, speech (of course, oral and printed), meetings, unions (Terjiman 1905a).

The Turkic version of this passage shifted the emphasis to the value of the Manifesto as a document that "opened up opportunities for freedom, recognition, and progress of all peoples." Still, if the Russian version presented the October Manifesto as the realized "cherished dreams of people who truly love Russia," in Turkic it was qualified as a result of "the stubbornness of all nations and tribes of Russia" in their common will of freedom (Terjiman 1905a).

Additionally, of particular interest was the Terjiman's coverage of the establishment of the State Duma and the elections of its deputies. Cer- 
tainly, this first-ever democratic election in the Russian Empire was a significant political development. For Muslims, it meant the possibility of political representation as a particular group of Russian subjects, which they subsequently gained while forming a small but self-interested Muslim faction in the second-forth State Dumas. In this sense, a number of active Muslim voters was potentially crucial in regard to a number of Muslim deputies. Hence, the Terjiman, seeking to establish the dominant discourse among Muslims, was used as a platform for political agitation:

Although the elections will be regional, regardless to the social class, ethnicity, or religion, it would be desirable that the Duma included representatives of all Russian peoples... If Muslims wish, within the election process to the Duma they could support such persons who knows their condition and can speak and act for them (Terjiman 1905b).

In a similar vein, the Terjiman closely covered the process of establishing the cultural-political association of Russian Muslims, the Ittifak al-muslimin (Muslim Union), which, however, never became an official political party due to its self-dissolution in 1907. Thus, while describing the first congress of Ittifak in Nizhny Novgorod in August 1905, the Russian version of the Terjiman stated the internal consolidation of Russian Muslims and the liberation from their inter-confessional disagreements, with the aim of showing Russian-speaking readers that Muslims were united in their socio-political demands. It was crucially important for the Ittifak, which was intended to serve as the associated voice of all Muslims in Russia regardless of their confessional differences or political views:

It is very significant and gratifying that in business as well as in the public sphere, Shiites, Sunnis, and Shaf' is have almost completely merged, burying in oblivion the sad traditions that once alienated them. It was also gratifying to hear moderate and honest judgments of Muslims regarding the duty and benefits of going in with the best people and forces of the great homeland (Terjiman 1905d).

The same passage in Turkic, targeting Muslim readers and denoting them as "people of the Quran"," did not mention the existence of internal contradictions between Muslims. Namely, the unity in interests and intentions of all Russian Muslim subjects, which did not and could not exist de-facto, was presented as de-jure existent due to their common religion, Islam. At the same time, emphasis on the common desire of Muslims to provide benefits to the state along with "such lovers of 
progress and justice as Russians," in this sense, meant the popularization of a statist position among Russian Muslims, as Gasprinskii considered the Russian Empire to be the only polity to realize his national intentions (Terjiman 1905d).

\section{Conclusion}

The prominent Terjiman newspaper served as an important informational platform, promoting the progressist ideas of its editor-in-chief, Ismail Gasprinskii, and his supporters among Muslims in Russia and beyond.

The so-called common-Turkic language, used in the newspaper along with Russian, was, due to its developing literary norm, eclectic in both its vocabulary and its grammar. However, this language unsuccessfully intended to develop to a status of common literary language for Russian Muslims.

Being a monopolist in the Muslim press until 1905, the Terjiman used its symbolic power to establish the dominant discourse among Russian Muslims (namely, the progressist) as well as to specify the appearance of a common literary language (namely, common-Turkic) in terms of defining linguistic habitus for Russian Muslims.

Still, if the usage of the Turkic language marked the national intention of its editor-in-chief Gasprinskii, the usage of the Russian language showed the Terjiman's inclusion in all-Russian imperial discourse, for instance, in regard to usage of the official terminology to cover the socio-political realities of the Russian Empire.

At the same time, there were several remarkable differences in its Russian and Turkic narratives. While in Russian (namely, for Russian readers) the editorial staff distinctly emphasized the internal unity of Muslims and their loyalty to the Russian authorities, especially during the revolutionary events of 1905, in Turkic (namely, for Muslim readers) the emphasis was shifted mostly to the internal interests of Muslims and the necessity of their loyalty. That is, an instance of cultural bilingualism of the Terjiman served to retranslate the same information for two different audiences.

Gasprinskii was one of the "legislators" in terms of the appearance of the common-Turkic language, therefore affecting the linguistic habitus of the Muslim audience as well as features of the Terjiman's bilingualism. Thus, he could choose whether some Russian terms, which did not have direct translations in Turkic, would simply be transliterated into Arabic script or would be adapted using most-likely equivalents.

While in Russian (namely, for Russian readers) the editorial staff distinctly emphasized the internal unity of Muslims and their loyalty to the Russian authorities, especially during the revolutionary events of 1905 , in Turkic (namely, for Muslim readers) the emphasis was shifted mostly to the internal interests of Muslims and the necessity of their loyalty. 
The Terjiman's bilingualism, therefore, should be qualified as a particular approach that the editorial staff used in an attempt to carry out their position comprehensively. It expresses the instances of both cultural bilingualism, simultaneously addressing its Muslim and non-Muslim audiences, and symbolic power, establishing a dominant discourse and linguistic habitus for Russian Muslims.

\section{References}

Akçura, Yusuf. 1978. Türkçülüğün Tarihi Gelişimi. İstanbul: Özdemir Basınevi.

Arapov, Dmitriy. 2012. "Stolypin i islam." Rossiyskaya istoriya 2: 121-6. Bessmertnaya, Olga. 2019. "Ponimaniye istorii i identichnost' avtora v vozrazheniyakh Ataully Baiazitova Ernestu Renanu.” Islamology 9(1-2): 54-82.

Bourdieu, Pierre. 1991. Language and Symbolic Power. Cambridge: Polity Press.

Findley, Carter V. 2008. "The Tanzimat." In The Cambridge History of Turkey, edited by Reşat Kasaba, 11-34. Cambridge: Cambridge University Press.

Gankevich, Yuriy. 2001. "Ismail Gasprinskii: Arkhivniye dokumenty k renney biografii." Gasyrlar Avazy 1-2: 136-41.

Gökalp, Ziya. 2017. Türkçülüğ̈̈n Esasları. İstanbul: Anonim Yayıncılık. Gubaydullin, Gaziz. 1997. "Gasprinskii i yazyk." Gasyrlar Avazy 3/4: 208-214.

Judson, Peter M. 2016. The Habsburg Empire: A New History. Cambridge, Massachusetts: The Belknap Press of Harvard University Press.

Kerimov, Ismail. 1999. Gasprinkiinin "janly" tarihi, 1883-1914. Simferopol: Tarpan.

Khalid, Adeeb. 1998. The Politics of Muslim Cultural Reform: Jadidizm in Central Asia. Berkeley: University of California Press.

Kırımlı, Hasan. 2001. Ismail Bey Gaspıralı. Ankara: Kırım Türkleri Kültür ve Yardımlaşma Derneği Genel Merkezi Yayınları.

Kurkchi, Usein. 1986. Fikir incileri. Tashkent: Gafur Gulam adına edebiyat ve sanat neşriyatı.

Landa, Robert. 2011. Rossiya i mir rossiyskogo islama. Moscow: Medina. Lazzerini, Edward. 1992. "Ismail Gasprinskii's Perevodchik/ Tercüman: A Clarion of Modernizm." In Central Asian Monuments, edited by Hasan B. Paksoy, 43-156. Istanbul: Isis press. 
Lotman, Yuriy. 1992. Stat'i po semiotike kultury i iskusstva. Tallinn: Aleksandra.

Samoylovich, Aleksandr. 1916. Opyt kratkoy krymsko-tatarskoy grammatiki. Petrograd: Tipografiya I. Voroganskogo.

Terjiman. 1883. “Iz Shushi nam pishut...” Terjiman, October 12, 1883. 1890. "Zynjyrly medrese." Terjiman, February 18, 1890.

1903. "Vozvrachsheniye iz Turtsii." Terjiman, January 7, 1903. 1905a. “17 Oktyabrya 1905.” Terjiman, October 21, 1905.

1905b. "Gosudarstvennaya Duma i vybory chlenov." Terjiman, 23 August, 1905.

1905.

-. 1905d. "Musulmanskiy s'yezd." Terjiman, August 26, 1905.

. 1905e. "Po povodu bakinskoy boyni." Terjiman, February 22, 1905.

1905f. "Vazhnoye vremya." Terjiman, March 11, 1905.

1905g. "Vopros o yazyke." Terjiman, November 4, 1905.

1905h. “Znamenatel'no.” Terjiman, November 4, 1905.

1905i. "Do sego vremeni..." Terjiman, December 3, 1905.

1905j. "Til, til, til.” Terjiman, December 9, 1905.

Tsibenko, Veronika, and Nadezhda Tikhonova. 2019. "Gasprinskii's Nation-Building Project through its Reflection in 'The Perevodchik-Terjiman' Newspaper." Bylye Gody 54(4): 1613-22. https://doi. org/10.13187/bg.2019.4.1613.

Tuna, Mustafa. 2002. "Gaspirali v. Il'minskii: Two Identity Projects for the Muslims of the Russian Empire." Nationalities Papers 30(2): 265-89. https://doi.org/10.1080/00905990220140658.

- 2017. "Pillars of the nation': The making of Russian Muslim Intelligentsia and the origin of Jadidism." Kritika: Explorations in Russian and Eurasian History 18(2): 257-81. https://doi.org/10.1353/ kri.2017.0018.

Yaman, Ertuğrul. 2002. İsmail Gaspıralı ve Ortak Türkçe. Ankara: Alternatif Yayınları. 
NADEZHDA TIKHONOVA-is a postdoctoral research fellow at the Centre for Historical Research, Higher School of Economics (HSE), Saint-Petersburg; PhD in History (Candidate of Historical Sciences), defense of a thesis in Kuban State University, Krasnodar; Graduate degree, Asian and African History, Saint-Petersburg State University, Saint-Petersburg. Her research interests include turcology and history of late-imperial Russia, with a special focus on the intellectual history of Russian Muslims.

\section{Address:}

Promyshlennaya Street 17A

St. Petersburg

198099

email: nadezhdatikhonova@yahoo.com

\section{Citation:}

Tikhonova, Nadezhda. 2021. "The Perevodchik-Terjiman Newspaper: A Bilingual Phenomenon of the Muslim Press in Late Imperial Russia." Praktyka Teoretyczna 1(39): 119-136.

DOI: $10.14746 /$ prt2021.1.6

Acknowledgments: This article is an output of a research project implemented as part of the Basic Research Program at the National Research University Higher School of Economics (HSE University).

Autor: Nadezhda Tikhonova

Tytuł: Gazeta Perevodchik-Terjiman. Przykład dwujęzycznej prasy muzułmańskiej w późno imperialnej Rosji

Abstrakt: Prezentowane studium przypadku bada dwujęzyczność kluczowej gazety rosyjskich muzułmanów z przełomu dziewiętnastego i dwudziestego wieku za pomocą analizy dyskursu. Gazetę Perevodchik-Terjiman (w przekładzie „Tłumacz”) publikowano od 1883 do 1918 na Krymie, a jej redaktorem naczelnym był Ismail Gasprinskii (1851-1914), ważny działacz edukacyjny wśród rosyjskich muzułmanów. Do grudnia 1905 roku gazeta była dwujęzyczna, publikowano ją po rosyjsku i w języku ogólno-tureckim. Ten drugi miał się stać językiem literackim dla zamieszkujących imperium rosyjskie muzułmanów. Pomimo deklaracji, artykuły nie były dosłownymi tłumaczeniami i różniły się między sobą w kluczowych punktach. Nie chodziło jednak o zwykłe zatajenie czegoś przed niektórymi czytelnikami. Artykuł ten dowodzi, że jest to przykład bilingualizmu kulturowego, odzwierciedlającego wielokulturowość odbiorców gazety.

Słowa kluczowe: dwujęzyczność, gazeta Perevodchik-Terjiman, Ismail Gasprinskii, język ogólno-turecki, późnoimperialna Rosja, rewolucja 1905 w Rosji, rosyjscy muzułmanie 